\title{
Antioxidant activity of ethanolic extract of inflorescence of Ormenis Africana in vitro and in cell cultures
}

Riadh Ben Mansour ${ }^{1 *}$, Bochra Gargouri ${ }^{1}$, Mohamed Bouaziz ${ }^{2}$, Nésrine Elloumi ${ }^{1}$, Imtinène Belhadj Jilani ${ }^{3}$, Zaineb Ghrabi ${ }^{3}$ and Saloua Lassoued ${ }^{1}$

\begin{abstract}
Background: The antioxidant potency of the hydroethanolic extract of Ormenis Africana (HEOA), Asteraceae was evaluated with regards to total polyphenol, flavonoid and anthocyanins content. Antioxidant activity has been assessed chemically and biologically. First, the free radical scavenging ability of HEOA was evaluated using two commonly in vitro tests: ABTS and DPPH radicals. Then, the protection effect of this extract against oxidative stress was conducted in HeLa cells treated with $\mathrm{Fe}^{2+}$ or $\mathrm{H}_{2} \mathrm{O}_{2}$. Oxidative stress was evaluated by measuring the lipid peroxidation levels (TBARs and DC) and the antioxidant enzymes activities (catalase and Superoxide dismutase). Cytotoxic effect of HEOA was prealably determined against HeLa cell line by MTT assay.
\end{abstract}

Results: HEOA contain considerable levels of antioxidant compound as evidenced by high amount of polyphenols (312.07 mg GAE/g dray matter), flavonoids (73.72 $\pm 1.98 \mathrm{mg} \mathrm{QE} / \mathrm{g}$ dray matterl) and anthocyanins (0.28 $\pm 0.09 \mathrm{mg}$ Cy-3-glu E/g dray matter). DPPH and ABTS assays showed a high antioxidant activity $\left(\mathrm{IC}_{50}=24 \mu \mathrm{g} / \mathrm{ml} ; \mathrm{TEAC}=\right.$ $2.137 \mathrm{mM}$ ) which was comparable to BHT.

In biological system, HEOA exhibited a 50\% cytotoxic concentration evaluated as $16.52 \mu \mathrm{g} / \mathrm{ml}$. Incubation of HeLa cell line with no cytotoxic concentrations resulted in a remarkable protection from oxidative stress induced by $\mathrm{Fe}^{2+}$ or $\mathrm{H}_{2} \mathrm{O}_{2}$ which was evidenced by a decrease of MDA and $\mathrm{CD}$ levels as well as a diminution of antioxidant enzymes activities (Catalase and SOD) as compared to cells treated with $\mathrm{Fe}^{2+}$ or $\mathrm{H}_{2} \mathrm{O}_{2}$ alone.

Conclusion: The hydroethanolic extract of $\mathrm{O}$. Africana could thus be considered as a source of potential antioxidants. The results of this study will promote the reasonable usage of this plant in food and pharmacy industries as well as in alternative medicine and natural therapy.

\section{Background}

Plants have been used for medicinal purposes since time immemorial. They have been screened for their potential uses as alternative remedies for the maintenance of health. It has been estimated by WHO (World Health Organization) (2002) that about $90 \%$ of the world's population from developing countries rely mainly on traditional medicines (mostly derived from plants) for their primary health care $[1,2]$. Plant compounds are used for protection and treatment of human diseases such as coronary heart disease and cancer. They are also

\footnotetext{
* Correspondence: riadhbm2004@yahoo.fr

'Unité de recherche Biotechnologie et pathologies, Institut Supérieur de Biotechnologie de Sfax, Tunisia

Full list of author information is available at the end of the article
}

used as a food conservator. The therapeutic benefits of the medicinal plants are often attributed to their antioxidant properties in relation to their large content on antioxidant compounds such as vitamin C, Vitamin E, polyphenol and flavonoïdes [3-6].

Ormenis Africana has been used in several centuries for traditional medicine. This plant is endemic in North Africa (Tunisia, Algeria and Morocco). In Tunisia, it is traditionally used for its hypoglycemic effect as well as for the treatment of stomacal pain. Traditionally the inflorescences of this plant are mixed with honey and used for the treatment of the cardialgia ulcer and stomacal pain.

As far as we know, there is no scientific exploration of the antioxidant capacity of $O$ Africana extract. In this

\section{Biomed Central}


regard, the purpose of this study was to evaluate the hydroethanolic extract of this plant as new potential source of natural antioxidants. First, the investigation of the flaavonoid, anthocyanin and total polyphenol content of the extract was conducted. The antioxidant activity was then chemically determined by in vitro assay (DPPH and ABTS scavaging activity) and biologically using the HeLa cell line. The cytotoxic effect of this extract was preliminary determined by MTT assay so all the used concentrations didn't show any cytotoxic affect for the cell culture.

\section{Results}

Total phenolic, anthocyanins and flavonoid compounds (chemical composition)

First, we was interested to evaluate the levels of anthocyanins, total phenolic and flavonoïd compounds in the hydroethanolic extract of Ormenis Africana (HEOA) using $\mathrm{pH}$ differential method, Follin-Ciocatleau colorimetric and $\mathrm{AlCl}_{3}$ methods, separately. The results show that HEOA contain $0.28 \pm 0.09 \mathrm{mg}$ Сy3-glu E/ g DM, $312.07 \pm 4,81 \mathrm{mg} \mathrm{GAE} / \mathrm{g} \mathrm{DM}$ and $73.72 \pm 1.98 \mathrm{mg} \mathrm{QE} / \mathrm{g} \mathrm{DM}$ of the assessed compounds respectively (Table 1 ).

\section{Antioxidant potential}

The HEOA was screened for its antioxidant capacity by DPPH and ABTS radicals scavenging assays (Table 2). It exerted an antioxidant activity which was comparable to that BHT as shown by ABTS assay (TEAC $=2.137$ vs $2.81 \mathrm{mM}$ ). However, the DPPH assays shown that BHT exhibited higher antioxidant activity than the plant extract $\left(\mathrm{IC}_{50}=24 \mathrm{vs} 8.31 \mu \mathrm{g} / \mathrm{ml}\right)$.

\section{Cytotoxicity effect of Ormenis Africana extract}

To investigate the cytotoxic effect of HEOA on HeLa human cell line, cells were treated with various concentrations of HEAO ranging from 0 to $50 \mu \mathrm{g} / \mathrm{ml}$ for 72 hours, and then submitted to the MTT test (figure 1). Data showed that HEOA displayed an inhibition effects on human cells growth in a dose dependent manner. The $\mathrm{IC}_{50}$ of HEOA was evaluated to $16.52 \mu \mathrm{g} / \mathrm{ml}$. Hence doses under this concentration were used for biological antioxidant activity investigation. Two doses of the extract were chosen: 5 and $10 \mu \mathrm{g} / \mathrm{ml}$ which induce less than $20 \%$ cytotoxicity.

Table 1 Concentration of total phenolics, flavonoïds and anthocyane in hydroethanolic extract of Ormenis Africana (HEOA) inflorescences

\begin{tabular}{cc}
\hline Total phenol content (mg GAE/g dray matter) & $312.07 \pm 4,81$ \\
\hline Flavonoides (mg QE/ g dray matter) & $73.72 \pm 1.98$ \\
\hline Anthocyane (mg Cy-3-glu E/ g dray matter) & $0.28 \pm 0.09$ \\
\hline
\end{tabular}

Table 2 ABTS and DPPH IC hydroethanolic extract of Ormenis Africana (HEOA) flowering summits and BHT

\begin{tabular}{ccc}
\hline Sample & ABTS values (TEAC) & DPPH IC $_{\mathbf{5 0}}$ values $(\boldsymbol{\mu g} / \mathbf{m l})$ \\
\hline HEOA & $2.137 \pm 0.12$ & $24 \pm 1.57$ \\
\hline BHT & $2.81 \pm 0,13$ & $8.31 \pm 0.2$ \\
\hline
\end{tabular}

\section{Biological antioxidant activity in human cell culture Lipid peroxidation}

The investigation of the biological antioxidant activity of HEOA was carried in the HeLa human cell line. Cells were cultured with or without addition of HEOA for 72 hours. Oxidative stress was induced by adding $100 \mu \mathrm{M} \mathrm{Fe}{ }^{2+}$ solution (as $\mathrm{Fe}_{2} \mathrm{SO}_{4}$ ) in PBS for one hour. Malondialdehyde and conjugated diene production, two lipid peroxydation markers were evaluated.

The oxidative treatment resulted in at least 13 fold increase in TBARs concentration compared with control cells. As shown in figure $2 \mathrm{a}$, a significant protection against ROS inducing damage was obtained with both used concentrations in a dose dependent manner. In fact, a significant decrease in TBARs level was obtained with the concentration of $5 \mu \mathrm{g} / \mathrm{ml}$ as compared to $\mathrm{Fe}^{2+}$ treated cells $(\mathrm{p}<0.05)$, while a total reestablishment of TBARs level was obtained with the concentration of $10 \mu \mathrm{g} / \mathrm{ml}$ as compared to untreated cells ( $\mathrm{p}>0.05$ ).

Concomitantly, HeLa cells treatment with HEOA exhibited an antioxidant effect evidenced by a decrease in conjugated diene level with both used concentrations as compared with $\mathrm{Fe}^{2+}$ treated cells alone. In contrast to TBARs data, there is no correlation between the

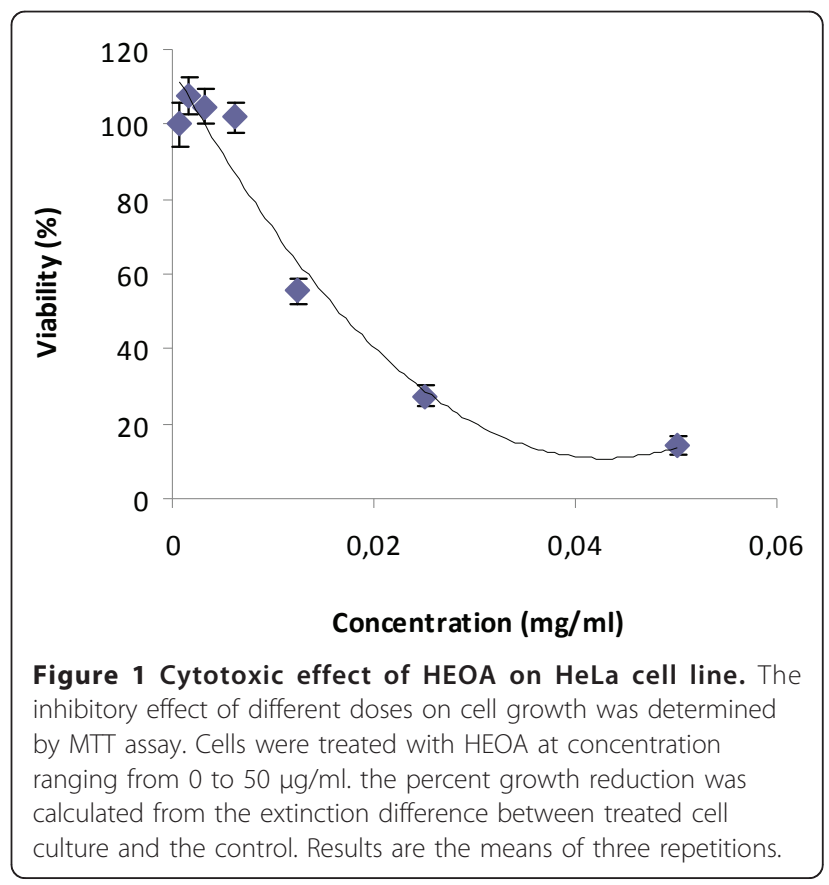




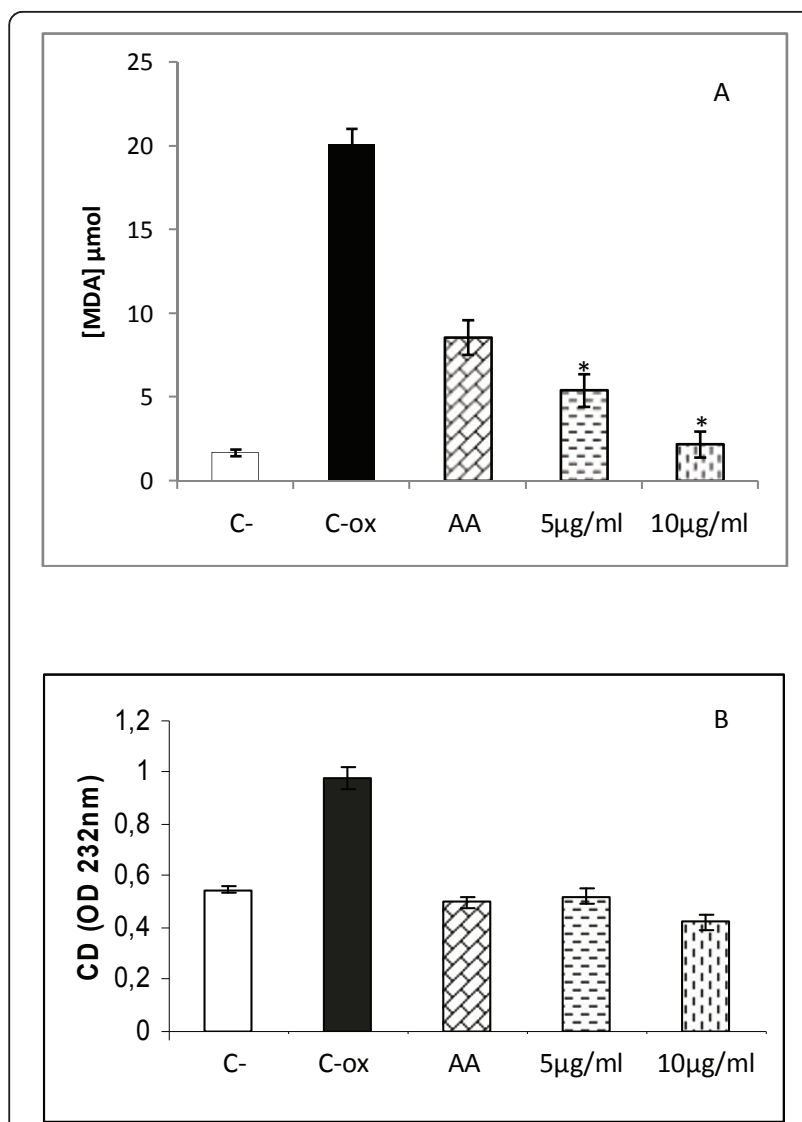

Figure 2 MDA (A) and conjugated diene (B) levels in HEOA supplemented HeLa cell line. Cells were cultured in $25 \mathrm{~cm}^{2}$ flasks with 5 and $10 \mu \mathrm{g} / \mathrm{ml}$ of HEOA for 72 hours. Oxidative stress was induced by addition of $\mathrm{Fe} 2+$ to the cells for 1 hour at a final concentration of $100 \mu \mathrm{M}$. TBARs and conjugated diene (CD) were compared to untreated cells (C-), cells treated with Fe2+ alone (Cox) and cells treated with $100 \mu \mathrm{M}$ ascorbic acid (AA).

concentrations used and the antioxidant activity was observed (figure 2b).

\section{Antioxidant enzyme activities}

Bioactivity of HEOA on SOD and catalase antioxidant enzymes was measured in HeLa cells. As shown in table 3 , induction of oxidative stress with $\mathrm{H}_{2} \mathrm{O}_{2}$ led to an increase in the SOD and catalase activities which can be explained by an adaptation of the enzymatic antioxidant system of the cells to the ROS production. Interestingly,

Table 3 Effect of HEOA cells pretreatment on Catalase and Superoxide dismutase activities

\begin{tabular}{ccc}
\hline Enzymes & Catalase $(\mathrm{U} / \mathrm{ml})$ & SOD (\% of inhibition) \\
\hline $\mathrm{C}-$ & $44.5 \pm 7.77$ & $26.5 \pm 4.94$ \\
\hline $\mathrm{C}-\mathrm{ox}$ & $126.5 \pm 9,19$ & $90 \pm 7.07$ \\
\hline \multicolumn{3}{c}{$\mathrm{HEOA}(\mu \mathrm{g} / \mathrm{ml})$} \\
\hline 5 & $58.16^{* *} \pm 5,8$ & $75 \pm 7.9$ \\
\hline 10 & $43.5^{* *} \pm 4,9$ & $69 \pm 6.7$ \\
\hline
\end{tabular}

the treatment of cells with both concentrations of HEOA induced a significant decrease in the catalase activities $(\mathrm{p}<0.05)$. A slight decrease in SOD activity was also obtained after treatment with HEOA but it was not statistically significant $(\mathrm{p}>0.05)$.

\section{Discussion}

Plants contain different groups of phenolic compounds, including simple phenolics, phenolic acids, anthocyanins, hydroxycinnamic acid derivatives and flavonoids. All the phenolic classes have received considerable attention because of their physiological functions, including free radical scavenging [7]. The antioxidant activity of phenolics is mainly due to their redox properties which make them act as reducing agents, hydrogen donors, and singlet oxygen quenchers. They may have also a metal chelating potential [8].

In this study, we assessed for the first time, the chemical composition of the HEOA of Ormenis Africana specie. The content on total polyphenols, anthocyanins and flavonoids was determined. No references concerning the total phenolic content of OA species could be found despite the thorough literature survey. These results showed that the extract is rich on total polyphenol content as compared to plants that belong to the same family (Asteraceae) such as the Helichrysum noeanum (312.07 vs $163.63 \mathrm{mg}$ GAE/g DM) [9-11]. Besides, flavonoids and anthocyanins, as estimated by $\mathrm{pH}$ differential and $\mathrm{AlCl}_{3}$ methods respectively are present in high concentrations compared to other alcoholic extracts from other Asteraceae species [10]. These preliminary results, suggest an anti-radical property of the HEOA. The free radical scavenging activity was determined through the DPPH test and the ABTS assay. The concentration of antioxidant needed to decrease the initial DPPH concentration by $50 \%\left(\mathrm{IC}_{50}\right)$ is a parameter widely used to measure antioxidant activity. As the $\mathrm{IC}_{50}$ value of the extract decreases, the free radical scavenging activity increases. The investigated extract expressed the ability to scavenge the stable DPPH free radical reaching $50 \%$ of reduction with an $\mathrm{IC}_{50}$ values of $24 \mu \mathrm{g} / \mathrm{ml}$ which is higher than the $\mathrm{IC}_{50}$ determined by the BHT as a positive control $(8,31 \mu \mathrm{g} / \mathrm{ml})$. However, the same extract showed a comparable antioxidant activity to BHT using the ABTS radical. Indeed, the $\mathrm{IC}_{50}$ of our extract was evaluated at $2.1 \mathrm{mM}$ TEAC versus 2,81 for the BHT. Indeed, in the present study it is found that the aqueous ethanol extract of Ormenis Africana inflorescences contains substantial amount of phenolics and it is the extent of phenolics present in this extract being responsible for its marked antioxidant activity as assayed through tow in vitro models. Several reports have shown close relationship between total phenolic contents and antioxidative activity of the fruits, plants and 
vegetables [11-14]. The chemical composition and chemical structures of active extract components are important factors governing the efficacy of natural antioxidants. Concerning the HEOA, further studies are needed for the isolation and identification of individual phenolic compounds and the assessment of their antioxidant activities. For instance, it has already been reported that phenolic compounds with ortho- and para-dihydroxylations or a hydroxy and a methoxy group or both are more effective than simple phenolics [15].

Our results are in agreement with those described for other extracts from plants belonging to the Asteraceae family. Indeed, the methanolic extracts and fractions from Achillea showed scavenging activity towards hydroxyl radical in different in vitro systems $[16,17]$. The ethyl acetate and the butanol fraction of Achillea extract showed a significant reduction of hydroxyl radical in different in vitro systems such as liver homogenate, hemolyzed blood, serum and postmitochondrial liver fraction [17]. The hydroethanolic extract of Ormenis Africana exhibited a higher antioxidant scavenging activity compared to other alcoholic extracts from Helichrysum and Achillea (methanol or ethanol) $[11,18]$.

The biological antioxidant activity of HEOA was also investigated in the HeLa cell culture. Considering that the chemical composition of the HEOA is not determined previously, we initially carried out control experiments to assess the cytotoxicity of our extract on HeLa cell line using MTT assay. The results showed that the extract had a cytotoxic effect in a dose dependent manner with an $\mathrm{IC}_{50}$ value evaluated as $16,52 \mu \mathrm{g} / \mathrm{ml}$. In order to investigate the antioxidant activity of our extract on cells model, we choose two concentrations that induce less than $20 \%$ of toxicity according to the results showed in figure 1 . The concentrations used are 5 and $10 \mu \mathrm{g} / \mathrm{ml}$ in all the experiences. HeLa cells are subjected to oxidation by $\mathrm{Fe}^{2+}$ solution $\left(\mathrm{Fe}_{2} \mathrm{SO}_{4}\right)$, to assess lipid peroxidation, or hydrogen peroxide, to assess antioxidant enzymes activities. The oxidative treatment with $100 \mu \mathrm{M} \mathrm{Fe}^{2+}$ resulted in the increase of MDA and $\mathrm{CD}$ levels due to the enhancement of the lipid peroxidation reaction. The pretreatment of cells by the HEOA resulted in the reduction of the production rate of the two considered markers as shown in figure 2. Moreover, the addition of $\mathrm{H}_{2} \mathrm{O}_{2}$ in the culture medium resulted in an increase of the catalase and superoxide dismutase activities. It's well known that catalase convert hydrogen peroxide into oxygen and water. The increase of the activity of this enzyme can be considered as an adaptation response to the addition of $\mathrm{H}_{2} \mathrm{O}_{2}$ in the culture media. The standard substrate of SOD is the superoxide anion which was dismutated to hydrogen peroxide. However, it was recently reported that at high level of $\mathrm{H}_{2} \mathrm{O}_{2}$ this enzyme, especially the MnSOD, enhanced the reverse reaction yielding to superoxide anion [19] which can explain the increased SOD activity after the treatment with hydrogen peroxide. The addition of the HEOA in the culture medium restored the activity of catalase (table 3) and lead to a decrease in SOD activity. This result could be explained by the reestablishment of the oxidant/antioxidant balance in the cell line and confirm the antioxidant property of our extract. This antioxidant activity could be explained by the high content of the HEOA on polyphenol, flavonoid and anthocyanins. Our results are in agreement with those found by other reports. In fact, Tuberoso et al (2009) [20] reported that the hydroalcoholic extracts from Achillea spp (Asteraceae) reduce significantly the production of MDA on caco-2 pretreated cells.

The results of this study revealed that the hydroethanolic extract of Ormenis Africana's inflorescences contain a considerable amount of polyphenol, flavonoid and anthocyanin compounds, and had significant antioxidant activity as determined by chemical and biological assays. The inflorescence of Ormenis Africana could be used as a potential source of natural antioxidants and bioactive molecules.

\section{Materials and methods}

\section{Plant materials and extraction procedure}

The inflorescence of Ormenis africana was harvested from the region of Kef (North West of Tunisia) and used as plant materials in this work. The inflorescences were dried at room temperature and $100 \mathrm{~g}$ of plant material were treated overnight with water:ethanol 20:80 $(\mathrm{v} / \mathrm{v})$ under gentile stirring. The hydroethanolic extract was filtered through a cellulose filter, lyophilized and frozen at $-80^{\circ} \mathrm{C}$ until use.

\section{Total phenol determination}

Total phenols were determined by using the FolinCiocalteu reagent according to the method of Singleton and Rossi [21]. Briefly, a $50 \mu \mathrm{l}$ aliquot of the extract was assayed with $250 \mu \mathrm{l}$ Folin reagent and $500 \mu \mathrm{l}$ of sodium carbonate $(20 \%, \mathrm{w} / \mathrm{v})$. The mixture was vortexed and diluted with water to a final volume of $5 \mathrm{ml}$. After incubation for $30 \mathrm{~min}$ at room temperature, the absorbance was read at $765 \mathrm{~nm}$. Total phenols were expressed as gallic acid equivalents (GAE), using a calibration curve of a freshly prepared gallic acid solution. For the gallic acid, the curve absorbance versus concentration is described by the equation $y=0.0012 x-0.0345\left(R^{2}=0.9997\right)$.

\section{Total flavonoid Determination}

Total flavonoids were measured by a colorimetric assay developed by Zhishen et al (1999) [22]. One millilitre of a diluted sample was added to $4 \mathrm{~mL}$ of water and $300 \mu \mathrm{l}$ of $\mathrm{NaNO}_{2}(5 \%, \mathrm{v} / \mathrm{v})$ in water was added. After $5 \mathrm{~min}$ of 
incubation, $300 \mu \mathrm{L}$ of $10 \% \mathrm{AlCl}_{3}$ was added. After $6 \mathrm{~min}, 2 \mathrm{~mL}$ of aqueous $\mathrm{NaOH}(1 \mathrm{M})$ was added to the mixture. Immediately; the mixture was diluted with water to $10 \mathrm{~mL}$. The absorbance was read at $510 \mathrm{~nm}$. Total flavonoids were expressed on a dry weight basis as quercetin equivalents, using a calibration curve of a freshly prepared quercetin solution. For quercetin, the curve absorbance versus concentration is described by the equation $y=0.0049 x\left(R^{2}=0.9984\right)$.

\section{Total anthocyanins measurement using $\mathrm{pH}$ differential method}

Total anthocyanins were measured according to a modification of the methods described earlier [23,24]. Two dilutions of the sample were prepared, one for $\mathrm{pH} 1.0$ using potassium chloride buffer $(0.03 \mathrm{M}, 1.9 \mathrm{~g} \mathrm{KCl}$ into $980 \mathrm{~mL}$ distilled water) and the other for $\mathrm{pH} 4.5$ using sodium acetate buffer $\left(0.4 \mathrm{M}, 54.4 \mathrm{~g} \mathrm{CH}_{3} \mathrm{CO}_{2} \mathrm{Na} .3 \mathrm{H}_{2} \mathrm{O}\right.$ in $960 \mathrm{~mL}$ distilled water). Samples were diluted 10 times to a final volume of $2 \mathrm{~mL}$. The absorbance of each sample was measured at $520 \mathrm{~nm}$ against distilled water as blank. The samples had no haze or sediment and thus correction at $700 \mathrm{~nm}$ was omitted. The concentration $(\mathrm{mg} / \mathrm{L})$ of each anthocyanin was calculated according to the following formula:

$$
\frac{A \times M W \times D F \times 10^{3}}{\varepsilon}
$$

and expressed as Cy-3-glc equivalents:

where $A$ is the absorbance $=\left(A_{\lambda \text { vis-max }}\right)_{\mathrm{pH}} 1.0-$ $\left(A_{\lambda \text { vis-max }}\right)_{\mathrm{pH} 4.5}, M W$ is the molecular weight $(\mathrm{g} / \mathrm{mol})$ $=449.2 \mathrm{~g} / \mathrm{mol}$ for Cy-3-glc, $D F$ is the dilution factor (0.2 $\mathrm{ml}$ sample is diluted to $2 \mathrm{ml}, D F=10)$, and e is the extinction coefficient $\left(\mathrm{L} \mathrm{x} \mathrm{cm}{ }^{-1} \mathrm{x} \mathrm{mol}^{-1}\right)=26,900$ for Cy-3-glc, where $L$ (path length in $\mathrm{cm}$ ) $=1$. For comparison, the same extinction coefficient was used for other standards to calculate the concentration of each anthocyanin and thus results reported is expressed as Cy3-glc equivalents.

\section{Free radical scavenging activity \\ DPPH Radical Scavenging Assay}

The hydrogen atom or electron donation ability of the corresponding extracts and some pure compounds was measured from the bleaching of purple coloured methanol solution of DPPH. The DPPH (1,1-diphenyl-2picrylhydrazyl) radical-scavenging effect was evaluated following the procedure described in a previous study [25]. In succinct terms, aliquots $(50 \mu \mathrm{L})$ of various concentrations of the test compound in methanol were added to $5 \mathrm{~mL}$ of a $0.004 \%$ methanol solution of DPPH. After a $30 \mathrm{~min}$ incubation period at room temperature the absorbance was read against a blank at $517 \mathrm{~nm}$.
Inhibition free radical DPPH in percent (I\%) was calculated in the following way: $I \%=\left[\left(A_{\text {blank }}-A_{\text {sample }}\right) /\right.$ $\left.A_{\text {blank }}\right] \times 100$, where $A_{\text {blank }}$ is the absorbance of the control reaction (containing all reagents except the test compound), and $\mathrm{A}_{\text {sample }}$ is the absorbance of the test compound. Test compound concentration providing $50 \%$ inhibition $\left(\mathrm{IC}_{50}\right.$, expressed in $\mu \mathrm{g} \mathrm{mL}^{-1}$ ) was calculated from the graph plotted inhibition percentage against extract concentration. Synthetic antioxidant butylated hyroxytoluene (BHT) was used as positive control and all tests were carried out in triplicate.

\section{Trolox equivalent antioxidant capacity (TEAC)}

The Trolox equivalent antioxidant capacity (TEAC) measures the reduction of the radical cation of ABTS by antioxidants. This assay was performed as previously described [26]. Briefly, ABTS radical cation $\left(\mathrm{ABTS}^{\circ+}\right)$ was produced by reacting ABTS stock solution with $2.45 \mathrm{mM}$ potassium persulfate (final concentration) and by allowing the mixture to stand in the dark at room temperature for 12- 24 h before use. For the study of phenolic compounds the $\mathrm{ABTS}^{\circ+}$, the solution was diluted with water to an absorbance of $0.70( \pm 0.02)$ at $734 \mathrm{~nm}$. For the photometric assay 1 $\mathrm{ml}$ of the $\mathrm{ABTS}^{\bullet+}$, the solution and $100 \mu \mathrm{L}$ antioxidant solution were mixed for $45 \mathrm{~s}$ and measured immediately after $5 \mathrm{~min}$ at $734 \mathrm{~nm}$ (absorbance did not change significantly up to $10 \mathrm{~min}$ ). Compounds were assayed at five different concentrations determined within the linear range of the dose-response curve. A calibration curve was prepared with different concentrations of Trolox (0-20 $\mu \mathrm{M})$. Results were expressed in $\mathrm{mM}$ of Trolox.

\section{HeLa cell culture}

The continuous human cell lines HeLa (epithelial cervical cancer cell line) was investigated for cytotoxicity and antioxidant effect of plant extracts. This adherent cell line was grown in RPMI 1640 medium (Gibco) supplemented with $10 \%(\mathrm{v} / \mathrm{v})$ foetal calf serum (FCS) and $2 \mathrm{mM}$ L-glutamin in tissue culture flasks (Nunc). It was passed twice a week and kept at $37^{\circ} \mathrm{C}$ in a humidified atmosphere of $95 \%$ air and $5 \% \mathrm{CO}_{2}$.

\section{Induction of oxidative stress}

Cells were adjusted to $510^{5}$ cells/ $\mathrm{ml}$ in $25 \mathrm{~cm}^{2}$ flasks, and incubated at $37{ }^{\circ} \mathrm{C}$. Oxidative stress was induced, after $72 \mathrm{~h}$, by addition of $\mathrm{Fe}^{2+}$ (as $\mathrm{Fe}_{2} \mathrm{SO}_{4}$ ) to the cells at a final concentration of $100 \mu \mathrm{M}$, for $1 \mathrm{~h}$. The oxidation was performed in phosphate buffered saline (PBS).

To evaluate superoxide dismutase (SOD) and catalase activities, oxidative stress was induced using $100 \mathrm{mM}$ $\mathrm{H}_{2} \mathrm{O}_{2}$ during 1 hour. The activities of catalase and SOD were assessed in cell lysates. 


\section{Malondialdehyde (MDA) determination}

For evaluation of MDA production rate, thiobarbituric acid-reactive species (TBARs) assay was used. Adherent cells were detached using trypsin/EDTA solution and centrifuged at $3000 \mathrm{rpm}$ for $10 \mathrm{~min}$. The pellet was resuspended in $500 \mu \mathrm{L}$ of deionized water and lysed by five cycles of sonication during $20 \mathrm{~s}$ at 35\% (Sonisc, vibracell). One millilitre of TBA solution (15\% trichloroacetic acid, $0.8 \%$ thiobarbituric acid, $0.25 \mathrm{~N} \mathrm{HCl}$ ) was added. The mixture was heated at $95^{\circ} \mathrm{C}$ for $15 \mathrm{~min}$ to form MDA-TBA adduct. Optical density (OD) was measured by a spectrophotometer (Biochrom, Libra S32) at $532 \mathrm{~nm}$. Values were reported to a calibration curve of 1,1,3,3-tetraethoxypropane (1.1.3.3 TEP).

\section{Antioxidant effect}

To assay the capacity of plant extract to protect HeLa cells from ROS-mediated oxidative injury, cells were preincubated for $72 \mathrm{~h}$ in the presence of different concentrations of ethanol extracts. At the end of the preincubation time, the medium was changed before the addition of the oxidative stress-inducing agent $(100 \mu \mathrm{M}$ of $\mathrm{Fe}_{2} \mathrm{SO}_{4}$ or $100 \mathrm{mM}$ of $\mathrm{H}_{2} \mathrm{O}_{2}$ ). Finally, the above mentioned markers were evaluated.

Different controls were used: (i) HeLa cells without any treatment; (ii) HeLa cells with $100 \mu \mathrm{M} \mathrm{Fe}^{2+}$; (iii) HeLa cells with $100 \mu \mathrm{M}$ of ascorbic acid

\section{MTT cell proliferation assay}

The MTT (3-(4,5-dimethylthiazolyl-2)-2,5-diphenyltetrazolium bromide) cell proliferation assay measures the cell proliferation rate and conversely, the reduction in cell viability when metabolic events lead to apoptosis or necrosis. The yellow compound MTT (Sigma) is reduced by mitochondrial dehydrogenases to the water insoluble blue formazan compound, depending on the viability of the cells.

Cells $\left(310^{4}\right.$ cells $/ \mathrm{ml}$ ) were grown on microtiter plates (200 $\mathrm{\mu l}$ of cell suspension/well) in 96 well microplates with serial dilutions of extract. $72 \mathrm{~h}$ later, $20 \mu \mathrm{l}$ of a MTT solution (5 $\mathrm{mg} / \mathrm{ml}$ in PBS) were added in each well. The plate was incubated for $4 \mathrm{~h}$ at $37^{\circ} \mathrm{C}$ in a $\mathrm{CO}_{2}$ incubator. After incubation, $180 \mu \mathrm{l}$ of medium were removed from each well and $180 \mu \mathrm{l}$ of DMSO/methanol (50:50) were added to each sample. The preparations were mixed thoroughly on a plate shaker with the cells containing formazan crystals. When all the crystals were dissolved, absorbance was measured at $570 \mathrm{~nm}$ with a microplate reader (Elx 800 microplate reader).

\section{Determination of catalase activity}

Catalase activity was measured as described previously by Aebi [27]. This method is based on the principle that the absorbance at $240 \mathrm{~nm}$ decreases because of dismutation of $\mathrm{H}_{2} \mathrm{O}_{2}$. The amount of $\mathrm{H}_{2} \mathrm{O}_{2}$ converted into $\mathrm{H}_{2} \mathrm{O}$ and $\mathrm{O}_{2}$ in 1 min under standard conditions is accepted as the enzyme reaction velocity. The number of catalase units was determined as follows: $\mathrm{U} / \mathrm{mL}=[(3.45 \% \text { slope }) / 0.05]^{*}$ $(1000 / 50 \mu \mathrm{l})$.

\section{Determination of SOD activity}

The SOD activity was determined by spectrophotometry (420 nm) using the pyrogallol assay as described previously [28] and modified as follows: the rate of autoxidation of pyrogallol in Tris-cacodylic acid diethylenetriaminepentaacetic acid (DTPA) buffer (pH 8-8.2) was determined (A1). The autoxidation of pyrogallol was evaluated under the same conditions after addition of $25 \mu$ l of cells lysate (A2). The percentage inhibition of pyrogallol oxidation was determined using the formula: \% Inhibition $=[(\mathrm{A} 1-\mathrm{A} 2) /$ A1]*100.

\section{Statistical analysis}

Each value is the mean of three replications. Values of different parameters were expressed as the mean \pm standard deviation $(x \pm S D)$. The one-way analysis of variance (ANOVA) was performed at the level of $\mathrm{p}<0.05$ to evaluate the significance of differences between mean values. Statistical analysis was performed using SPSS (SPSS 13 for Windows) statistical software.

\section{Abbreviations}

DM: Dry matter; DPPH: 1,1-diphenyl-2-picrylhydrazyl; FCS: Foetal calf serum; GAE: Gallic acid equivalent; HEOA: Hydroethanolic extract of Ormenis Africana; MDA: Malodialdehyde; OA: Ormenis Africana; PBS: Phosphate buffer saline; ROS: Reactive oxygen species; SOD: Superoxide dismutase; TBA: Thiobarbuturic Acid; TBARs: Thiobarbuturic Acid Reactive species; TEAC: Trolox equivalent antioxidant capacity; TEP: 1,1,3,3-tetraethoxypropane.

\section{Author details}

${ }^{1}$ Unité de recherche Biotechnologie et pathologies, Institut Supérieur de Biotechnologie de Sfax, Tunisia. ${ }^{2}$ Laboratoire des Bioprocédés, Pôle d'Excellence Régionale AUF, (PER-LBP) Centre de Biotechnologie de Sfax, BP: «1177», 3038 Sfax, Tunisia. ${ }^{3}$ Laboratoire de production fouragère et pastorale, Institut National d'Agronomie de Tunisie, Tunisia.

\section{Authors' contributions}

RBM and BG prepared the study design, carried out all the biological studies, analyzed and discussion of the data, and drafted the manuscript. MB helped with chemical analysis of the extract and correction of the manuscript. NE carried out some biological assays and helped with the manuscript preparation. IBJ and ZG give us the plant material. SL participated in the study design, discussion the data and helped to draft and correction of the manuscript. All authors have read and approved the final manuscript.

\section{Competing interests}

The authors declare that they have no competing interests.

Received: 15 April 2011 Accepted: 16 May 2011 Published: 16 May 2011

\section{References}

1. Astin JA, Marie A, Pelletier KR, Hansen E, Haskell WL: A review of the incorporation of complementary and alternative medicine by mainstream physicians. Archives of Internal Medicine 1998, 158:2303-2310. 
2. Yawar A: Spirituality in medicine: what is to be done? Journal of the Royal Society of Medicine 2001, 94:529-533.

3. Hertog MG, Feskens EJ, Hollman PC, Katan MB, Kromhout D: Dietary antioxidant flavonoids and risk of coronary heart disease: the Zutphen Elderly Study. Lancet 1993, 23:1007-11.

4. Zhang Z, Chang Q, Zhu M, Huang Y, Ho WK, Chen Z: Characterization of antioxidants present in hawthorn fruits. J Nutr Biochem 2001, 12:144-152

5. Rice-Evans C: Flavonoids and isoflavones: absorption, metabolism, and bioactivity. Free Radic Biol Med 2004, 36:827-8.

6. Dixon RA, Xie DY, Sharma SB: Proanthocyanidins-a final frontier in flavonoid research? New Phytol 2005, 165(1):9-28.

7. Bandoniene D, Murkovic M: On-line HPLC-DPPH screening method for evaluation of radical scavenging phenols extracted from apples (Malus domestica L.). Journal of Agricultural and Food Chemistry 2002, 50(248):2-2487.

8. Pietta PG: Flavonoids as antioxidants. Journal of Natural Products 2000, 63:1035-1042.

9. Tepe B, Sokmen M, Akpulat HA, Sokmen A: In vitro antioxidant activities of the methanol extracts of four Helichrysum species from Turkey. Food Chemistry 2005, 90:685-689.

10. Carvalhoa IS, Cavaco T, Brodelius M: Phenolic composition and antioxidant capacity of six artemisia species. Industrial Crops and Products 2011, 33:382-388.

11. Bouaziz M, Dhouib H, Smaoui S, Loukil S, Boukhris M, Sayadi S: Polyphenols, antioxidant and antimicrobial activities of some wild medicinal plants collected in southern Tunisia. African Journal of Biotechnology 2009, 8(24):7017-7027.

12. Albayrak S, Aksoy A, Sagdic O, Hamzaoglu E: Compositions, antioxidant and antimicrobial activities of Helichrysum (Asteraceae) species collected from Turkey. Food Chemistry 2010, 119:114-122.

13. Bouaziz M, Grayer RJ, Simmonds MSJ, Damak M, Sayadi S: Identification and antioxidant potential of flavonoids and low molecular weight phenols in olive cultivar Chemlali growing in Tunisia. J Agric Food Chem 2005, 53:236-241.

14. Shahidi F, Marian N: Phenolics in food and nutraceuticals. CRS Press LLC, Boca Raton, FL 2003, 1:144-150

15. Abdille MH, Singh RP, Jayaprakasha GK, Jena BS: Antioxidant activity of the extracts from Dillenia indica fruits. Food Chemistry 2005, 90(4):891-896.

16. Shahidi F, Naczk M: Food phenolics: Sources, Chemistry,Effects and Applications. Lancaster, PA 2004.

17. Sökmen A, Sökmen M, Daferera D, Polissiou M, Candan F, Ünlü M, Akpulat HA: The in vitro antioxidant and antimicrobial activities of the essential oil and methanol extracts of Achillea biebersteini Afan. (Asteraceae). Phytother Res 2004, 18:451-456.

18. Kundakovic TN, Mimica Dukic N, Kovacevic : Free radical scavenging activity of Achillea alexandri-regis extracts. Fitoterapia 2005, 76:574-576.

19. MacMillan-Crow LA, Crow JP: Does More MnSOD Mean More Hydrogen Peroxide? Anti-Cancer Agents in Medicinal Chemistry 2011.

20. Tuberoso CIG, Montoro P, Piacente S, Corona G, Deiana M, Dessì MA, Pizza C, Cabras P: Flavonoid characterization and antioxidant activity of hydroalcoholic extracts from Achillea ligustica All. Journal of Pharmaceutical and Biomedical Analysis 2009, 50:440-448.

21. Singleton VL, Rossi JA: Colorimetry of total phenolic with phosphomolibdic phosphotungstic acid reagents. Am J Enol Vitic 1965, 16:144-158.

22. Zhishen J, Mengcheng T, Jianming W: The determination of Flavonoid contents in mulberry and their scavenging effects on superoxide radicals. Food Chem 1999, 64:555-557.

23. Fuleki T, Francis FJ: Determination of total anthocyanin and degradation index for cranberry juice. Food Science 1968, 33:78-83.

24. Lee J, Durst RW, Wrolstad RE: Determination of total monomeric anthocyanin pigment content of fruit juices, beverages, natural colorants, and wines by the $\mathrm{pH}$ differential method: Collaborative study. Journal Association of Official Analytical Chemists International 2005, 88(5):1269-1278

25. Bouaziz M, Jemai H, Khabou W, Sayadi S: Oil content, phenolic profiling and antioxidant potential of the main tissues of Tunisian olive drupes. Journal of Food Science and Agriculture 2010, 90:1750-1758.

26. Re R, Pellegrini N, Proteggente A, Pannala A, Yang M, Rice-evans C: Antioxidant activity applying an improved ABTS radical cation decolorization assay. Free Radicals Biol Med 1999, 26:1231-1237.
27. Aebi H: Catalase in vitro. Methods Enzymol 1984, 105:121-6.

28. Jiang $X$, Chen F: The effect of lipid peroxides and superoxide dismutase in systemic lupus erythematosus: a preliminary study. Clin Immunol Immunopathol 1992, 63:39-44.

doi:10.1186/1476-511X-10-78

Cite this article as: Ben Mansour et al:: Antioxidant activity of ethanolic extract of inflorescence of Ormenis Africana in vitro and in cell cultures. Lipids in Health and Disease 2011 10:78.

\section{Submit your next manuscript to BioMed Central and take full advantage of:}

- Convenient online submission

- Thorough peer review

- No space constraints or color figure charges

- Immediate publication on acceptance

- Inclusion in PubMed, CAS, Scopus and Google Scholar

- Research which is freely available for redistribution

Submit your manuscript at www.biomedcentral.com/submit
Ciomed Central 